\title{
John Italos Seen by Anna Komnene
}

\section{MAGDALENA JAWORSKA-WOEOSZYN / Gorzów /}

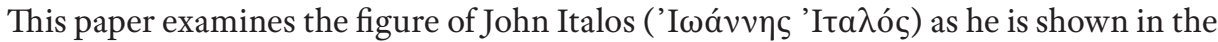

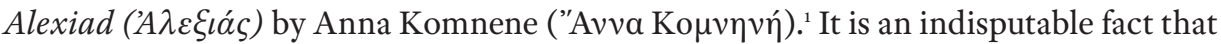
the historical opus of Komnene is one of the main sources which provides crucial information about this eminent Byzantine thinker. ${ }^{2}$ However, it is worth emphasizing that

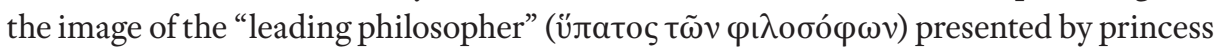
Komnene is of a very specific nature. Indeed, although a proper picture of John Italos (as a very controversial person and thinker) is shown from a variety of different perspectives, his character is consistently portrayed in a negative way. Thus, the aim of this paper is to

1 The primary monographs on John Italos are: Stephanou (1949); Joannou (1956) and Clucas (1981). Particular attention should also be given to Niarchos (1978) and Macdonald (1982), albeit these are unavailable to a wider audience.

2 Apart from the surviving documents on Italos' trial (edited by Успенский in 1897), The Alexiad of Komnene is clearly one of the main sources on this subject, see Gouillard (1967: 188) and Clucas (1981: 178-179). 
unravel those elements hidden in the Alexiad which caused Anna Komnene to express such an opinion about this Byzantine thinker.

\section{Princess and her opus}

Anna Komnene was born in 1083 in the so-called Purple Chamber. She was the eldest child of the Emperor Alexios Komnenos I and his wife Irene Doukaina. Carrying out the will of her father, she was betrothed to Constantine Doukas (previously adopted by Alexios I) and, as a result, for some time she hoped it would be her to take over the power. In 1087 with the birth of John, the son of the imperial couple, Anna Komnene irretrievably lost the opportunity to become an empress and it seems that she never came to terms with her fate. After the death of her spouse (about 1095), she returned from his family home to the imperial palace. It was then that she began to deepen her knowledge and develop her academic skills. Apart from broadly defined literature, among Anna's main interests there were mathematics, rhetoric, theology, astrology and last but not least philosophy and medicine. One passage from the preface of the Alexiad confirms her exceptional erudition.

I, Anna, the daughter of two royal personages, Alexius and Irene, born and bred in the purple. I was not ignorant of letters, for I carried my study of Greek to the highest pitch, and was also not unpractised in rhetoric; I perused the works of Aristotle and the dialogues of Plato carefully, and enriched my mind by the "quaternion" of learning. (I must let this out and it is not bragging to state what nature and my zeal for learning have given me, and the gifts which God apportioned to me at birth and time has contributed). ${ }^{3}$

When she was fourteen years old, she got married to her father's loyal subject Nikephoros Bryennios. Urged by her mother, Anna continually tried to persuade her husband to become the successor and take the power instead of John, if only the emperor agreed. However, Bryennios did not want to participate in his wife's intrigues and finally in 1118 - the throne was taken over by John. Due to the fact that Anna and her mother did not cease to plot against the new emperor, they were closed by him in Kecharitomene monastery, where in 1127 Irene Doukaina died. After the death of her mother and Nikephoros Bryennios, namely around 1137, Anna began working on the Alexiad which she ultimately finished before her death.

Considering the times, Anna Komnene was certainly a woman of exceptional and extraordinary erudition. She became famous primarily as the author of the Alexiad which

${ }^{3}$ Alexiad (Preface, 1, 2). All quotations from Anna Komnene's the Alexiad appear in the translation by E.A.S. Dawes. 
can be considered the most outstanding work written by a woman in Byzantium. ${ }^{4}$ Historical in its essence, the Alexiad is not only a result of many years of work, but also an exciting story of the reign of Anna's father Alexios Komnenos. Importantly, the work of Anna Komnene, provides information about Emperor Alexios' activity, while, at the same time, showing other contemporary events in the political and cultural life in the Byzantine Empire. Therefore, it is not surprising that it also takes John Italos - the controversial philosopher of the eleventh century - into account.

\section{Selected facts of Italos' life}

Anna Komnene devotes several pages of her Alexiad to Italos. The character of John Italos is invoked by her at the end of the fifth volume of this historical work, and more specifically in the eighth and ninth chapters. A reference to John Italos appears also in the first chapter of the tenth volume of the Alexiad. ${ }^{5}$ It should be emphasized that a portrait of John Italos sketched by Komnene is very detailed. In fact, the author of the Alexiad not only presents the philosopher from the perspective of his activities and achievements in the capital of Byzantium, but also in the context of his origin and educational background. It cannot be forgotten that the account of Anna Komnene in a direct way refers also to the appearance and character traits of the thinker, which makes him more vivid and authentic.

This Italus (for it is necessary to give his history from the beginning) was a native of Italy and had spent a considerable time in Sicily; this is an island situated near Italy. For the Sicilians had rebelled against the Roman rule and were preparing for war against them and invited the Italians to join them; amongst those who came was the father of Italus who brought his son with him, although he was not of military age, and the boy accompanied and tripped along with him and received a military education, as is the custom of the Italians. That is how Italus spent the early years of his life, and that was the first foundation of his education (Alexiad V 8, 1).

With these words the actual fragment about the thinker begins. The Alexiad clearly shows that John Italos came from the southern areas of Italy and spent the first years of

4 On Anna Komnene and her Alexiad, see: Komnena (2005: v-xlvi); Jurewicz (1984: 228-233); Herrin (2007: 232-242); Smythe (2006: 125-141). Cf. also Komnene Anna in The Oxford Dictionary of Byzantium, ed. by A.P. Kazhdan, vol. 2, 1991: 1142.

5 At the beginning of the first chapter of the tenth volume, the character of John Italos was recalled by Komnene in the context of her statement about Nilus, a monk from Calabria, who shared the fate of Italos (Alexiad X 1, 1). As a self-appointed teacher, Nilus, similarly to John Italos, gathered around him many disciples and was accused of the proclamation of the content inconsistent with the doctrine of the Church. He was eventually condemned five years after Italos' conviction, i.e., around 1087. On Nilus, see Alexiad X 1, 1-5 and Meyendorff (1979: 40). 
his life with his father in Sicily. ${ }^{6}$ In addition, Komnene links the basics of the philosopher's education with the activities of his father, who was a Norman mercenary. In other words, the military activity of his father is supposed to determine the direction of the early education of John Italos.? According to the Alexiad:

When the famous George Maniaces during the reign of Monomachus mastered and subdued Sicily, the father of Italos with his child only escaped with difficulty and betook themselves in their flight to Lombardy which was still under the Romans. From there (I do not know how) this Italos came to Constantinople, which was not ill supplied with teachers of every subject and of the art of language (Alexiad V 8, 2). ${ }^{8}$

Anna Komnene indicates that Italos and his father after the outbreak of the rebellion by George Maniakes in 1043 got through to Lombardy and then in unknown circumstances eventually reached the capital of the empire. It is worth noting that the arrival of Italos in Constantinople coincided with the reign of Constantine IX Monomachos - a period of intellectual and cultural revival, whose ultimate advocate and guardian of tradition was for Komnene always her father - Emperor Alexios I (Alexiad V 8, 2). Then the princess' tale proceeds directly to the description of the initial activity of the thinker in the capital, according to which John Italos "consorted with the scholars, gloomy men of uncouth habits (for such were to be found in the capital even then) and after he had gained an education in letters from them he later associated with the renowned Michael Psellus (Alexiad V 8, 3)". Anna Komnene mentioning the education obtained by Italos in Constantinople thereby links the philosopher with unknown scholars and, above all, with the figure of Michael Psellos. ${ }^{9}$ It is known that Italos gained knowledge of literature from some scholars and then as a pupil of Psellos, he obtained extraordinary expertise of dialectics.

After pointing out the educators of John Italos, the Alexiad's author returns again to the themes of biographical nature. She evokes the figure of the contemporary Emperor Michael VII Dukas and his brothers, thanks to which she clearly emphasizes the friendly nature of the relationship between the imperial family and the thinker (Alexiad V 8, 4). ${ }^{10}$

6 It is an indisputable fact that John Italos was born in the southern part of Italy. On the origin of the philosopher, see Stephanou (1949: 15); Joannou (1956: 11-12); Arabatzis (2002: 403); Tatakis (1959: 210); Jurewicz (1987: 207); Angold (1995: 50); Romano (1998: 131); Rigo (2002: 63); Ierodiakonou (2011: 623); Jaworska-Wołoszyn (2010: 388).

${ }^{7}$ It is worth noting lack of reliable information on early education of John Italos during his stay in Italy, i.e., before his arrival to the capital of Byzantium.

${ }^{8}$ Owing to the fact that the author of the Alexiad connects the childhood of Italos with the activities of Maniakes, we gain the ability to determine the probable date of birth of the philosopher. It can be assumed that he was born around the year 1025, and came to the capital of Byzantine Empire at the age of nearly 30 years.

9 In light of modern research, other educators owing to whom John Italos broadened his knowledge, remain anonymous, apart from the philosophy lecturer and rector of the Imperial School of Constantinople - Psellos.

${ }^{10}$ According to various scholars, the thinker's intimate relations with the royal Dukas family must have had an impact on his trial at the time of Alexios I. On the political determinants of Italos' trial, see Joannou (1956: 27-28); Angold (1995: 50); Kečakmadze (1969: 176); Browning (1975: 12-13) and Hoyle (2011: 191). 
In the princess' text, Michael VII Dukas and his family's trust and appreciation towards Italos were reflected in the imperial decision to appoint him (at the time of the Normans expansion in Italy) as the emperor' messenger.

The Emperor of that time sent Italus to Epidamnus on the supposition that he was his friend and an honest man, and understood Italian affairs. Then, to cut my story short, he was detected in treachery to us and an official was sent to expel him, and Italus getting wind of this, escaped to Rome. Later, as was his nature, he repented and sent imploring letters to the Emperor who ordered him back to Constantinople and gave him as dwelling - place the monastery called Pege, and the church of the Forty Saints (Alexiad V 8, 5).

Komnene's account clearly shows that as a result of a wrong decision taken by the Emperor Michael VII Dukas, Italos was sent to Epidamnos (Dyrrachium). Indeed, between 1073 and 1074 the philosopher held talks there with the Patriarch of Grado, that is Dominic Marango and then as a result of a betrayal hastily made his way to Rome. ${ }^{11}$ Finally, after a short time spent in Rome he returned again to the land of Byzantium straight to Constantinople. After the act of repentance to the Emperor, John Italos completing the imperial will, settled in a monastery, as mentioned by the princess.

Later when Psellus left Byzantium after taking the tonsure, Italus became the foremost teacher of all philosophy and was styled the highest 'Hypatus of philosophers' and he gave lectures

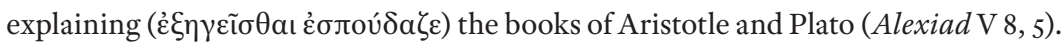

Continuing her story about John Italos, Komnene mentions that he was appointed to the position of the 'Consul of the Philosophers', previously occupied by his master Michael Psellos. Komnene suggests that this took place about the year 1055, and more precisely - when Psellos entered the monastery. ${ }^{12}$ According to Anna Komnene:

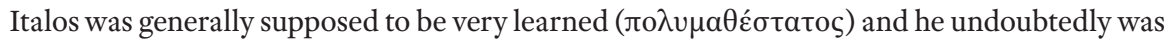
far cleverer ( $\delta \varepsilon \imath$ òç $\delta \grave{\varepsilon} \mu \tilde{a} \lambda \lambda o v)$ than all others in expounding that most wonderful philosophic system, the Peripatetic, and especially the dialectics of it. But for other branches of literature he had not a very good head, for he stumbled over grammar and had never tasted the nectar of rhetoric. Consequently his language was not adaptable nor at all polished (Alexiad V 8, 6).

${ }^{11}$ It is worth noting that Dominic Marango was sent to the lands of Byzantine Empire by Pope Gregory VII in 1073. The purpose of the patriarch's trip was to hold disputes that could overcome the split between the churches. Apart from that, the further fate of Marango remains unknown. He probably died between July 1073 and the second half of 1074. See Canzian (2007).

12 In all probability, Italos took the position after his master at the Imperial School of Constantinople at a later time, i.e., during the reign of Michael VII, or after the death of Psellos in 1078. See Browning (1975: 12); Rigo (2002: 64) and Jaworska-Wołoszyn (2010: 389). 
The Alexiad clearly shows that even though John Italos appeared as an outstanding expert in dialectics, the beauty of rhetoric art was unknown to him. Confirmation of that fact is consistent with his personal style of expression not only deprived of flowery but also lacking subtlety and sophistication. Moreover, Italos' heavy language, full of Aristotelian syllogisms, was intended to embarrass people engaged in the dialogue with him because it disturbed their peace of mind and made it impossible to provide proper answers to the previously posed questions (Alexiad V 8, 6). Further critical and hostile comments of Anna Komnene refer to the philosopher's pronunciation, which clearly revealed his provincial origins. As Komnene noted "his studies too had contracted his brows and he literally exhaled harshness (Alexiad V 8, 6)". Inevitably the imperfection of Italos' language determined the presence of numerous structural and grammar mistakes in his writings.

As a lecturer of philosophy John Italos had above all familiarized his students with the philosophical thought of Plato and Aristotle. It is known that besides the Platonic and Aristotelian concepts, he also lectured about the teachings of Neoplatonists, namely Proclus, Porphyry and Iamblichus (Alexiad V 9, 1). Italos also gathered around himself many listeners (people from the commonly recognized Byzantine families related to the political and spiritual sphere of Byzantium life), and his lectures received great acclaim. ${ }^{13}$ Anna Komnene mentions that among them there were: "Solomon John, and an Iasitas and Serblias and others devoted to learning maybe" (Alexiad V 9, 2), "who because of their master's keenness did not benefit from him and who used to visit the imperial palace" (Alexiad V 9, 1-2). It should be emphasized that according to Komnene:

They knew no literary subject accurately, but would pose as dialecticians, making ungainly movements and mad contortions of their limbs, they understood nothing sound but put forth ideas, even those about metempsychosis, in a shadowy way and other similar equally monstrous notions (Alexiad V 9, 2).

Referring to the pupils of Italos (who was highly respected at that time), the author of the Alexiad points out that due to the passage of time she cannot recall their names, but amongst them there were certainly people hostile to the Emperor (Alexiad V 9, 4). From the Alexiad we also learn that even before the rule of Alexios I, Italos used to show complete contempt for other people and raised his own disciples as rebels. Following the negative judgment of the philosopher's educational activities, Anna Komnene proceeds directly to the description of the most important and decisive moment in his life. She reports that when the Emperor:

\footnotetext{
13 Among Italos' pupils, there was Eustratius of Nicaea, Michael Matzos, Michael Doxopatres, John of Gangra and Abasgos (Ioane Petritsi). His teaching also influenced the Emperor Michael VII Dukas and his brother Andronikos.
} 
found Italus throwing everything into confusion and leading many astray, so he deputed the Sebastocrator Isaac to examine him, as he was very literary and accustomed to undertaking important duties. When Isaac found that Italus was as report said, he openly censured him in a public meeting and then passed him on to the ecclesiastical tribunal by order of the Emperor, his brother (Alexiad V 9, 5). ${ }^{14}$

The Emperor Alexios I, thus, instructed his brother Isaac to re-examine the content of Italos' doctrines for the presence of any heretical topics in it. ${ }^{15}$ As a result, around March 1082 his teachings were initially verified by the court, upon which the results of the investigation were submitted to the Patriarch Eustriatos Garidas to be finally assessed by the synod. The Patriarch was greatly influenced by Italos and his teaching. ${ }^{16}$ Though he had to contribute to the improvement of the philosopher, he almost began to share his dishonest opinions due to his fatal charm (Alexiad V 9, 5).

According to Komnene, the barbarian thinker even after receiving public reprimand from the Sebastokrator Isaac did not behave appropriately in the Great Church in the face of ecclesiastical dignitaries gathered there. Moreover, there was no end of his antics.

What was the consequence? The whole population of Constantinople surged into the church, shouting for Italus. Probably he would have been thrown down from the top into the middle of the church, had he not escaped to the roof of the sacred edifice and hidden himself in some hole he found (Alexiad V 9, 6).

Afterwards, Anna reports that the imperial intervention was indispensable in the case of John Italos, because his false doctrines, besides the Patriarch, seized the minds of too many courtiers. Consequently, Italos' teachings were considered to be contrary to the doctrine of the Church and were phrased in 11 anathemas, and the philosopher himself was forced by the Emperor to their public condemnation from the ambo of St. Sophia. Then, after saying each of the curses by the philosopher, the gathered crowd was to utter the words - "cursed" (Alexiad V 9, 4). ${ }^{17}$ Anna Komnene's account also shows that Italos

${ }^{14}$ In contrast to Anna Komnene's account, the trial shows something opposite, i.e. John Italos' own claims for vindication by the synod. See Clucas (1981: 17).

${ }^{15}$ For the first time, John Italos was accused of proclaiming heretical views during the reign of the Emperor Michael VII and Kosmas' Patriarchate. As a result of this, he was condemned by the Patriarch's synod of 1076-1077. His wrong doctrines were summarized in 10 anathemas. Importantly, however, John Italos was not named as their author due to the favor of the Emperor. It is worth noting that that preserved text of the trial does not mention anything about the fact that the Emperor Alexios I ordered that his brother Isaac should investigate the case of the philosopher. See Clucas (1981: 15).

${ }^{16}$ It is very likely that the notoriety which Italos enjoyed and the ability to convince others to himself as well as his teachings, were the cause of imperial intervention directed against the thinker.

17 Clucas notes that Komnene, evoking Italos' image and denouncing loudly 11 anathemas from the St. Sophia pulpit, at the same time confirms the report of the Third Synod. The anathemas read on the Sunday of Orthodoxy are those that were formulated by the synod in the years 1076-1077 and then assigned to the thinker in Synodikon. The one condemning Italos' views was added to them (at the time of Alexios I). On the other 
did not cease to proclaim his ideas, which led to the anathema being imposed on him (Alexiad V 9, 7). Later, when the thinker repented again, the curse cast on him was mitigated. Komnene reports that from that time:

his doctrines are still recited and cursed, his name is only mentioned indirectly, as it were, and secretly, and the anathema pronounced on him by the church is not pronounced in a voice audible to the congregation (Alexiad V 9, 7).

At the end of the narrative about John Italos, the princess recalls the figure of the philosopher who abandoned the theory of metempsychosis, questioning the importance of the holy icons and

he also remodeled his teaching about "ideas" so as to make it conform to orthodoxy, and it was quite evident that he condemned himself for having formerly strayed from the straight path (Alexiad V 9, 7). ${ }^{18}$

The appraisal of Anna Komnene remains closely connected with the life, competences and pedagogical activities of John Italos, but it never become positive. Suffice it to recall the origin of the philosopher, which made very unfavorable impression on the princess and the people from her circle. For Komnene, the thinker, originating from Italy, spoke his language incorrectly, displayed lack of grammar and rhetorical knowledge and diverged from the pronunciation of educated people keen on rhetoric art, to whom she herself belonged. Furthermore, the fact that Italos' statements referred to the simplicity of classical language determined the peculiar approach to the language as such. In contrast to Anna Komnene, he did not subordinate the content to the form, but rather valued more the thought, for which language is to serve only as a vehicle of expression. Certainly, Italos' beliefs (e.g., metempsychosis mentioned by the princess, the theory of ideas or denial of „holy icons”) contributed to the fully negative judgment of his person. Although the Alexiad shows that no one could equal the philosopher in terms of proficiency in the dialectics, at the same time, this knowledge reveals his contemptuous attitude towards the people with whom he was in touch. One should not ignore the fact that, according to Anna Komnene, John Italos did not respect his teachers (Alexiad V 8, 4), nor did his teaching carry any tangible benefits for his pupils (Alexiad V 9, 1). As a result, Komnene shows the thinker as a man seemingly comprehensive and well-educated, but predominantly a rebel and a traitor.

hand, this indicates that Anna Komnene wrongly connects the events from 1076 and 1077 with the subsequent events of the year 1082. As a result, she wrongly assumes that the 11 anathemas were formulated in 1082 . See Clucas (1981: 215-216) and Gouillard (1967: 191).

18 John Italos after admitting his own errors settled in the monastery. His further fate remains unknown. It is also important that the punishments of the Emporer Alexios affected the thinker' disciples. Under the threat of penalty, he was forbidden to provide them with a shelter. 
The Alexiad's author incorporated some short digressions about her mother and father into the story about the philosopher that perfectly emphasize the ideological gap between him and the imperial family. Moreover, the imperial couple passionately exploring the mysteries of Holy Scripture appears to be an antithesis to Italos. Anna evokes the image of her mother repeatedly studying the books of the Holy Fathers and the works of St. Maximus the Confessor at breakfast, since her main interest was not in the natural science, but in the dogmas that are the source of true wisdom (Alexiad V 9, 3). The princess, overwhelmed by the works that the Empress studied, does not hide her admiration. Komnene also recalls that one day she asked her mother "How can you spontaneously rise to such sublime heights?" (Alexiad V 9, 3) and that the mother's response really hurt her. In fact, the Empress told her that if she really desired to be able to benefit from these works and enjoy them, she should start from reading the less demanding ones. Komnene also evokes a figure of her father - the Emperor deploring the poor condition of literature and cultural life in Byzantium after coming to power and suggesting that people devoted to science should undertake the study of the sacred rather than pagan books (Alexiad V 9, 4). It appears that the presence of these incidental references is not without significance in Komnene's narrative. Undoubtedly, the Emporer Alexios' apologetic attitude towards the true faith cast a shadow on the life and activity of convicted of heresy and therefore an admirer of Hellenic wisdom - John Italos.

\section{The appearance and personality of John Italos}

In some passages of the Alexiad, the author evokes Italos' personality seen from the angle of his character traits or his appearance. According to Anna Komnene

his head was large, his brow very prominent, his face open, his nostrils wide and of free exhalation, his beard rounded, his chest broad and his limbs well-knit together, in stature shorter than the very tall (Alexiad $\mathrm{V} 8,8)$.

Thus, Italos for Komnene certainly did not stand out among others. She also suggests that he did not dazzle with beauty, nor did any charm accompany his person. In physical terms, John Italos can be described as an average person. However, further appraisal of the princess shatters that sense of neutrality in her account and also implies a different way of perceiving the thinker. According to Komnene, Italos personified a man whose

pronunciation was such as you would expect of a Latin who had come to our country as a young man and learnt Greek thoroughly but was not quite clear in his articulation, for he mutilated his syllables here and there. This want of clearness in his utterance and his dropping the last letters did not escape even ordinary people and made rhetoricians call him 'rustic' in his speech (Alexiad V 8, 8). 
Consequently, Italos' pronunciation not only reveals his ignorance in matters of rhetoric, but above all contributes to the perception of him as a stranger speaking a rustic dialect. Ultimately, the philosopher completely deprives the Greek language beloved by Komnene of all its beauty, because apart from imputed blameworthy language of a Latin, his writings also leave much to be desired. An unremarkable appearance is not able to bring John Italos to the Byzantine ideal, but on the contrary - confronted with others - he is seen as its negation. Compared with people of appropriate manners and impeccable education (Anna Komnene recalls, e.g., Autokrator Alexios I, his wife Irene or Sebastokrator Isaac), the philosopher does not prove to belong to the group of representatives of the traditional values of the Byzantine society and therefore they are out of his league. Moreover, for the Princess Italos poses a threat to the existing order and becomes someone who questions it. Similarly, his knowledge is only apparent and does not constitute real wisdom, which was the subject of interest and study of Anna's mother. Probably the unflattering opinion about Italos was also determined by the fact that he did not have a caring and devoted mother nearby, whereas his master Psellos managed to ascend to the heights owing to his mother's help. ${ }^{19}$ Recalling the figure of Michael Psellos, the Alexiad's author points out that the famous teacher of John Italos

through his natural cleverness and quick intelligence and further by the help of God (which he had obtained by his mother's ardent supplications, for she often spent whole nights in the church of God weeping and making invocations to the holy picture of the Virgin on her son's behalf) he had reached the summit of all knowledge (Alexiad V 8, 3).

Taking into account lack of any maternal care and concern in case of Italos, it should be emphasized that he is unable to match not only people from the circle of the imperial family, but even Psellos himself. Naturally, this striking dissonance in the presentation of two admirers of wisdom is deeply rooted in the excellent rhetorical preparation (so important for Komnene) of the master, which his student lacked.

In the historical work of Anna Komnene, special attention must be paid to those parts which are directly related to the character of John Italos, because getting to know the Byzantine thinker's lifestyle and behaviour leads to the knowledge of his real nature. Thus, Komnene stressed that

he was most unrefined, and subject to violent temper; and this fierce temper annulled and obliterated the credit he gained from his learning. For in arguments this man used fists as well as words and he did not allow his interlocutor simply to lose himself in embarrassment nor was he satisfied with sewing up his opponent's mouth and condemning him to silence, but forthwith his hand flew out to tear his beard and hair, and insult quickly followed insult, in fact the man could not be restrained in the use of his hands and tongue. The only unphiloso-

19 On the mother's role as an intermediary between children and God, see Arabatzis (2002: 207). 
phic trait he had was that after the blow his anger left him, tears and evident remorse followed (Alexiad V 8, 7).

This passage clearly depicts a person dependent on his own unrestrained emotions and devoid of good manners. Hence, this lack of control, so typical of John Italos, caused his conduct to deviate from the accepted patterns and his behaviour to be reprehensible. For Komnene, the uncouth nature and anger, under whose influence the thinker remained, deprived him of the ability to function properly in the field of science, and as a result he did not benefit at all from it. Moreover, Italos' negative traits influenced his relationships with other people. Talking to his interlocutors, he resorted to expressive gestures and even unacceptable physical contact. Although the philosopher was able to express his remorse, his constant crossing the lines when dealing with other people, gained him the opinion of a barbarian. This can be confirmed by passages in Anna Komnene's book in which she depicts John Italos' relationships with his teachers, Psellos, his pupils and even his attitude towards his accusers. Although he constantly accompanied Michael Psellos - his spiritual guide

he was never able to plumb the depths of philosophy for he was of such a boorish and barbarous disposition that he could not endure teachers even when learning from them. He was full of daring and barbarous rebelliousness and even before learning a thing, imagined he surpassed everybody else (Alexiad V 8,3).

According to Komnene, apart from his barbarous disposition, Italos was characterized by extraordinary courage and audacity towards his teachers. Indeed, according to the Alexiad the philosopher's relations with his teachers were neither peaceful nor successful; on the contrary - he fervently hated their critical comments. He had similar relationships with his pupils and as a result of his impetuosity and fickleness, they could not benefit from his teaching (Alexiad V 9, 1). It should be also stressed that the princess questions John Italos' behaviour even in the face of the synod. According to her account, the philosopher treated everyone with contempt and even "in the midst of the ecclesiastical dignitaries did not cease from acting like a buffoon, and doing other things of a boorish and uncultured nature" (Alexiad V 9, 5).

All this shows that the portrait of John Italos sketched by Anna Komnene is far from flattering. Regardless of the diverse range of perspectives and multiple representations of the philosopher, it is difficult to find in the Alexiad comments or opinions of positive nature. For Komnene, even an indisputable fact that he had no equals in the field of dialectics and seemed to be an unrivalled expert in Platonic and Aristotelian thought does not have much significance. Moreover, this competence, while undeniably confirming the uniqueness of the thinker, was underrated by the author of the Alexiad. This was certainly done intentionally, because Komnene's historical work is a story about the rule and achievements of her father. The emergence of controversial and disobedient Italos violated the order, and above all meant teaching innovative and bold concepts. As a result 
his passion for ancient wisdom, he was used by Anna Komnene to strengthen the image of Alexios I as an emperor and guardian of the true faith, fully devoted to orthodoxy. Even though Komnena depicted the great Consul of the Philosophers in a highly negative way, it is worth noting that this is not the only critical presentation of John Italos.

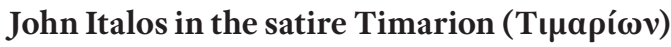

It seems that the historical presentation of John Italos in Anna Komnene's Alexiad bears resemblance to his satirical portrait presented in the anonymous Timarion ${ }^{20}$ written in the early twelfth century. ${ }^{21}$ Indeed, in both cases, the thinker is shown in an unfavorable way, and the elements that constitute the critical purport of his descriptions are of identical nature.

Even though John Italos was an expert on Aristotle, Plato and the art of dialectics, neither in the Timarion nor in the Alexiad was this fact appreciated. In the satire narrative, there are no positive references to the philosophical knowledge of Italos. In fact he is rejected by the representatives of philosophy, both rhetoric and sophistry. The philosopher summons his master Aristotle to help, but to no avail (Timarion 44). On the other hand, although some positive comments appear in the work of Anna Komnene, they lose their importance in the overall context of her very critical evaluation of the thinker.

In both works, we can find more analogous images and converging opinions about John Italos. One can recall him being attacked by rhetors and sophists in the Timarion to gain a conviction that they did so because he lacked knowledge of grammar and because his works were irrelevant. This image of Italos is confirmed by Anna Komnene, for whom the thinker clearly showed ignorance of not only grammar and different fields of literature, but especially rhetoric (Alexiad V 8,6). In the Alexiad, we can find criticism of his writings in which numerous shortcomings of grammatical and compositional nature appeared (Alexiad V 8,8).

It seems that when referring to Italos' character and his particular mode of action, the author of the Timarion follows the path paved by Anna Komnene. In the satire, the philosopher is seen as a person with incisive and acerbic tongue that intentionally deceives people (Timarion 43). For Komnene, a peaceful and constructive dialogue with the thinker was impossible, because not only did he wreak havoc in the souls of his interlocutors, but also repeatedly drove them to the point of no return (Alexiad V 8, 6).

20 The anonymous satire Timarion has been translated and edited several times. The most important of

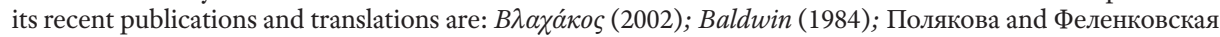
(1953) and Romano (1974). It should be also noted that the reprint of Romano translation's is to be found in La satira bizantina dei secoli XIV-XV (1999).

${ }^{21}$ Though the general date of the Timarion does not currently leave any doubts, the question of its authorship is still discussed by the scholars. On this subject, see Pseudo-Luciano (1974: 13); Beaton (2008: 333-335) and Timarion (1984: 28-32). 
The narrative of Anna Komnene also shows that Italos was extremely insolent, insulting and deprived of appropriate manners, a person who sometimes even got into physical contact with other people (Alexiad V 8, 7). One of the scenes of Timarion vividly and perfectly captures his reprehensible behavior and lack of control, as mentioned by the author of the Alexiad. Therefore, it is not surprising that in the satire Italos gets into a fight with Diogenes, bites him and carries out the discourse barking like a dog. According to Komnene, lack of restraint and indomitable audacity, that were characteristic of John Italos contributed to the fact that the thinker could not "explore philosophy" in the right way or use his knowledge adequately (Alexiad V 8, 3). In the Timarion this eminent dialectician, unexpectedly falls into the trap of Diogenes, takes his methods and in fact has nothing to say. Naturally, in this case, his knowledge is not the source of any benefit for him.

Undoubtedly, then, John Italos was not presented positively either in the satire by an anonymous author or in the historical work by Komnene. Indeed, whilst the satire introduces that eminent thinker from a perspective of parody with the aim of ridiculing him, in the Alexiad there is a noticeable distortion of analogous nature. The difference is that the basis of this deformity in the Timarion should be seen in terms of an overall critical attitude of the author towards cultural and intellectual life in the Byzantine Empire, whereas in the Alexiad it serves as an overt defense of this life. This does not change the fact that in both cases the final opinion about the famous "Consul Philosophorum" was formed only in unflattering and hostile statements. Italos was not recognized as an outstanding figure, but rather as a controversial thinker that hardly deserved any recognition. 


\section{BIBLIOGRAPHY}

\section{EDITIONS AND TRANSLATIONS}

Византийская сатира «Тимарион», 1953, С.В. Поляковой, И.В. Феленковской (transl.), Византийский Временник 6, pp. 357-386.

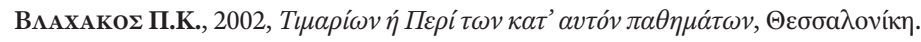

Comnène, A., 2006, L'Alexiad, Paris.

ИоАнн ИтАл, Апории, 2013, А.Е. Карначёва (transl.), СПб.: «Свое издательство», Seria Byzantina.

Kečakmadze N.N., 1966, Ioannis Itali Opera, Tbilisi.

Komnena, A., 1928, The Alexiad, E.A.S. Dawes (transl.), London.

Komnena, A., 1969-1977, Aleksjada, vol. I-II, O. Jurewicz (transl.), Wrocław.

Pseudo-Luciano, 1974, Timarione. Testo critico, introduzione, traduzione commentario e lessico, R. Romano (ed.), Napoli.

Timarion, 1984, Translated with Introduction and Commentary by Barry Baldwin, Detroit.

\section{STUDIES}

Alexiou, M., 2002, After Antiquity: Greek Language, Myth and Metaphor, New York.

Angelov, D., SAxby, M. (eds.), 2013, Power and Subversion in Byzantium Surrey and Burlington.

Angold, M., 1995, Church and Society in Byzantium under the Comneni 1081-1261, Cambridge.

Arabatzis, G., 2002, “Blâme du philosophe, éloge de la vraie philosophie et figures rhétoriques: le récit d’Anne Comnène sur Jean Italos revisité”, Byzantinische Zeitschrift 95, pp. 403-416.

Beaton, R., 2008, From Byzantium to Modern Greece. Medieval Texts and their Modern Reception, Aldershot.

Browning, R., 1975, “Enlightenment and repression in Byzantium”, Past and Present 69, pp. 3-23.

CANZIAN, D., 2007, „Marango Domenico”, in: Dizionario biografico degli Italiani, vol. 69, http://www.treccani. it/enciclopedia/domenico-marango_\%28Dizionario_Biografico\%29/ (08.06.2014).

Clucas, L., 1981, The Trial of John Italos and the Crisis of Intellectual Values in Byzantium in the Eleventh Century, München.

Cyran, G., Skorupska-Raczyńska, E. (red.), Język doświadczenia religijnego, t. III, Szczecin.

DuJČEv, I., 1939, “L’umanesimo di Giovanni Italo”, Studi Bizantini e Neoellenici 5, pp. 432-435.

Garcia Bravo, A., 2003, Pselo a Pletón: La filosofía bizantina entre tradición y originalidad, Ciencia y Cultura en la Edad Media, Canarias.

GARlAND, L. (ed.), 2006, Byzantine Women. Varietes of Experience ad 800-1200, Aldershot and Burlington.

GouILlARD, J., 1985, “Le procès officiel de Jean l' Italien. Les actes et leurs sous-entendus”, Travaux et Mèmoires 9, pp. 133-169.

Gouillard, J., 1967, Commentaire: Le Synodikon sous les Comnènes, Paris.

Gouma-Peterson, T., 2000, (ed.), Anna Komnene and Her Times, New York and London. 
HerRIN J., 2007, Byzantium: The Surprising Life of a Medieval Empire, London.

Homann, E., KrüGer, A. (hrsg.), (2007), De usu rationis. Vernunft und Offenbarung im Mittelalter, Würzburg.

Hoyle, M., 2011, “The Apostolic Emperor: Anna Comnena's Conceptualization of Alexios I” Chrestomathy 10, pp.189-203

Hussey, J.M., 1990, The Orthodox Church in the Byzantine Empire, Oxford.

IERodiakonou, K., 2007, Rationality and Revelation in Eleventh and Twelfth Century Byzantium, in: Homann, Krüger (2007), pp. 19-31.

IERODIAKoNOU, K., 2011, “John Italos”, in: Lagerlund (2011), p. 623.

JAworska-WoŁoszyn, M., 2010, „Jan Italos: kontrowersyjny 'konsul filozofów'”, in: Cyran, Skorupska-Raczyńska (2010), pp. 385-394.

Jaworska-WoŁoszyn, M., 2012, „Poza granicami wiary. Anatemy na Jana Italosa“, Filo-sofija 16, pp. 83-95. JUREwiCz, O., 2007, Historia literatury bizantyjskiej, Wrocław.

KeС̌AKмADZE, N., 1969, Из истории общественной мысли Византии в ХІ в., Византийский временник, t. XXIX, Москва, ss. 170-176.

Krallis, D., 2013, "Harmless satire, stinging critique: Notes and suggestions for reading the Timarion”, in: Angelov, Saxby (2013), pp. 221-245.

LAGERLund, H. (2011), Encyklopedia of Medieval Philosophy Heidelberg.

ЛурьЕ, В.М., 2006, История Византийской философии. Формативный период, СПб.

MACDONALD, J.L., 1982, The condemnation of John Italos, New York.

MEYendorfF, J., 1979, Byzantine Theology: Historical Trends and Doctrinal Themes, New York.

NiARchos C., 1978, God, the Universe, and Man in the Philosophy of John Italos, Oxford.

Rigo, A., 2002, “Giovanni Italo”, Dizionario biografico degli Italiani, vol. 56, http://www.treccani.it/enciclopedia/ giovanni-italo_\%28Dizionario-Biografico\%29/ (23.11.2014).

Smythe, D. C., 2006, Middle Byzantine Family Values and Anna Komnene's Alexiad, in: Garland (2006), pp. 125-139.

TатакIs, B., 1959, La philosophie byzantine, Paris.

УСпенский, Ф., 1897, „Делопроизводство по обвинению Иоанна Итала в ереси”, Известия Русского Археологического Института в Константинополе, vol. II, pp. 1-66.

M A G D A L E N A J A W O R S K A - John Italos Seen by Anna Komnene

- W O LOSZY N

/ Gorzów /

The historical work of Anna Komnene is one of the main sources which provides crucial information about John Italos. It is worth noting though that princess Komnene sketches in the Alexiad a portrait of this eminent Byzantine thinker that is anything but flattering. Despite the wide range of perspectives and diverse representations of the philosopher, it is actually quite difficult to find in her opus any comments or opinions of decisively positive nature. As a matter of fact, the final opinion regarding the famous "Consul Philosophorum" is formed solely on the basis of downright hostile statements. John Italos is not regarded as an outstand- 
KEY WORDS ing figure, but rather as a controversial thinker that hardly deserves any recognition. While the present paper investigates the figure of Italos as shown in the Alexiad by Anna Komnene, its aim is to unravel those elements in the work that caused Komnene to express such an opinion about the philosopher.

John Italos, Consul Philosophorum, The Alexiad of Anna Komnene, Timarion, satire. 